\title{
BLOOD VOLUME ALTERATIONS IN CONGESTIVE HEART FAILURE
}

\author{
By SIDNEY S. SCHREIBER, ARTHUR BAUMAN,1 ROSALYN S. YALOW, AND \\ SOLOMON A. BERSON
}

(From the Radioisotope Unit, Veterans Administration Hospital, Bronx, N. Y.)

(Submitted for publication August 6, 1953; accepted December 30, 1953)

A considerable body of data indicates that the plasma volume, as measured by dye dilution methods, is generally increased in congestive heart failure $(1-4)$. However, recent investigations, utilizing $\mathrm{P}^{82}(5,6)$ or $\mathrm{Cr}^{51}(7)$ tagged red cells, indicate that there is little or no increase in total blood volume, plasma volume, or red cell volume in most cases of heart failure.

According to presently accepted concepts, the total body relative cell volume,

$$
\frac{\mathrm{RBC} \text { volume }}{\mathrm{RBC} \text { volume }+ \text { plasma volume }} \text {, }
$$

is appreciably lower than the relative cell volume of the blood withdrawn from the large vessels (hematocrit value) (8-16), and the ratio between these two is not necessarily constant (17). It is, therefore, theoretically possible for total erythrocyte volume and venous hematocrit value to remain unchanged in the presence of a significant increase in plasma volume, if the ratio,

$$
\frac{\text { total body relative cell volume }}{\text { venous hematocrit value }}
$$

decreases. Some such mechanism suggests itself if the aforementioned discrepancies are to be satisfactorily resolved.

It was, therefore, considered to be of interest to reinvestigate the status of the blood volume in heart failure by performing simultaneous red cell and plasma volume determinations before and after compensation in a variety of cases of decompensated heart disease.

\section{METHODS}

Subjects were hospitalized male patients in whom the diagnoses (Table I) and the presence of congestive heart failure were verified by at least two observers. Fiftyseven studies were made on 26 subjects. Treatment of

1 National Heart Institute Research Fellow 1953-1954. the heart failure followed conventional lines, employing in various combinations, bed rest, low salt diet, digitalis substances, and diuretics as dictated by individual requirements. No attempt was made to regulate therapy in any special manner. A period of bed rest in the recumbent position for at least three hours preceded all determinations. Peripheral venous pressures and circulation times were determined in all cases simultaneously with the blood volume studies. Peripheral venous pressures were obtained in the recumbent subject with the manometer zeroed at a level $8 \mathrm{~cm}$. posterior to the manubro-sternal junction. Decholin sodium was employed for determination of the arm to tongue circulation times.

Erythrocyte volumes and plasma volumes were measured with $\mathrm{P}^{32}$ tagged erythrocytes and dialyzed solutions of $I^{121}$ labeled human serum albumin, respectively. The methods employed were the same as those previously described (16) except that weighed amounts of the tagged red cell suspensions and iodoalbumin solutions were administered within a minute of each other through the same needle. Each syringe was rinsed four times with the venous blood. The syringes were then assayed for residual radioactivity which was found to be negligible. Heparinized blood samples were withdrawn from a vein in the opposite arm 15, 20, and 25 minutes after injection. The $\mathrm{P}^{32}$ was assayed with a thin glass walled Geiger counter with a sensitivity of $32: 1$ for $\mathrm{P}^{32}$ as compared with $\mathrm{I}^{122}$, and the $I^{21}$ with a thick bismuth cathode Geiger tube which is almost insensitive to $P^{\prime 2}$. Sufficient counts were recorded for each assay to reduce the statistical error of counting to less than 1.5 per cent.

Venous hematocrit values were obtained by centrifugation at $3000 \mathrm{rpm}$. for 30 minutes and then multiplied by 0.98 to correct for trapped plasma (18). Since erythrocyte and plasma volumes were calculated from assays of whole blood samples, any systematic error in the correction factor was not critical to determinations of the ratio,

$$
\frac{\text { total body relative cell volume }}{\text { venous hematocrit value }} .
$$

2 This point is clarified by the following example. Assume that 2,000,000 counts of $P^{22}$ and $I^{131}$ each have been injected, that the counts per $\mathrm{ml}$. whole blood due to $\mathrm{P}^{*}$ and $I^{121}$ are 500 and 400 , respectively, and that the observed venous hematocrit is $\mathbf{5 0}$ per cent. Utilizing a correction factor of 2 per cent for trapped plasma results in calculated values of $1960 \mathrm{ml}$. RBC volume and $2550 \mathrm{ml}$. plasma 


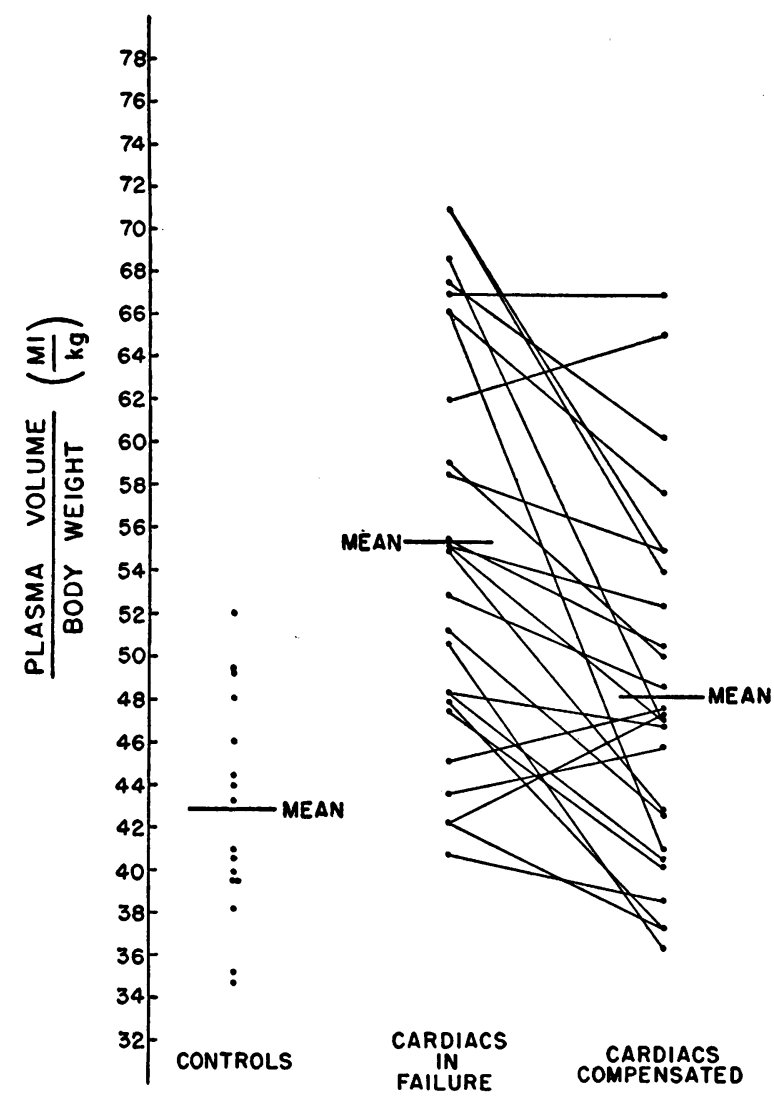

Fig. 1. Comparison of Plasma Volumes of Control Subjects with Those of Patients in Heart Failure AND AFTER COMPENSATION

There was no significant trend in the concentrations of the labeled plasma or tagged cells between 15 and 25 minutes. This confirms previous observations $(16,19)$ that, even in heart failure, mixing is essentially complete by this time.

\section{RESULTS}

Blood volumes are given as absolute values in milliliters (Table I) and as $\mathrm{ml}$. per $\mathrm{Kg}$. body weight (Figure 1). It has been shown that gain or loss in weight has no significant influence per se on plasma volume (20). Even in moderately severe

volume. The ratio, $\frac{\text { total body relative cell volume }}{\text { venous hematocrit value }}$, is then

$$
\frac{\frac{1960}{1960+2550}}{.49}=.887 \text {. }
$$

If instead, a correction factor of 10 per cent is used, then

$$
\frac{\text { total body relative cell volume }}{\text { venous hematocrit value }}=\frac{\frac{1800}{1800+2750}}{.45}=.879 \text {. }
$$

caloric starvation accompanied by losses of 25 per cent of the body weight (21), plasma volume remains unchanged in absolute values, thus increasing greatly in proportion to body weight. Cachexia will then tend to magnify any increase in blood volume when calculated in terms of body weight. Conversely, edema may obscure such changes. With a single exception (Case 26, C. C.) cachexia was not present in the subjects reported here. Therefore, the weights after restoration of compensation were taken as closest to the "normal" weights of the cardiac subjects and used as reference for all determinations in these cases.

\section{Plasma and erythrocyte volumes}

In 22 of the 26 patients studied, compensation was accompanied by a decrease in total blood volume ranging from 3.5 per cent to 23.0 per cent (Table I). In four of the subjects (Nos. 11, 17, $25,26)$ there was an increase in total blood volume following therapy of heart failure. However, in one of these (No. 17, I. S.) clinical improvement was equivocal and, in another (No. 11, L. I.), subsequent relapse into failure was associated with a marked increase in plasma volume which was retained after recompensation. The decrease in blood volume in the 22 patients was chiefly attributable to loss of plasma volume but in most of these, a fall in red cell volume was also noted. The plasma volumes in failure and following compensation were compared with a group of non-cardiac controls on the basis of volume per kilogram body weight (Figure 1). The mean plasma volume for the group of 16 non-cardiac subjects was $42.0 \pm 1.19^{3}$ $\mathrm{ml}$. per $\mathrm{Kg}$. which agrees well with other "normal" values obtained in this laboratory and elsewhere. The mean plasma volume for the group of $26 \mathrm{pa}$ tients in heart failure was $55.6 \pm 1.83 \mathrm{ml}$. per $\mathrm{Kg}$. and, after complete or partial compensation, was $48.2 \pm 1.61 \mathrm{ml}$. per $\mathrm{Kg}$. The average decrease in plasma volume was $430 \mathrm{ml}$. (12.2 per cent). The mean value for erythrocyte volumes during decompensation ( $39.2 \pm 1.83 \mathrm{ml}$. per $\mathrm{Kg}$.) was higher than that of a group of seven control subjects (32.2 $\pm 1.83 \mathrm{ml}$. per $\mathrm{Kg}$.), and the mean fall following compensation was $170 \mathrm{ml}$. ( 7 per cent).

${ }^{8}$ All values are expressed as mean values \pm standard error of the mean. 
TABLE I-Data pertaining to blood volume in cardiac patients

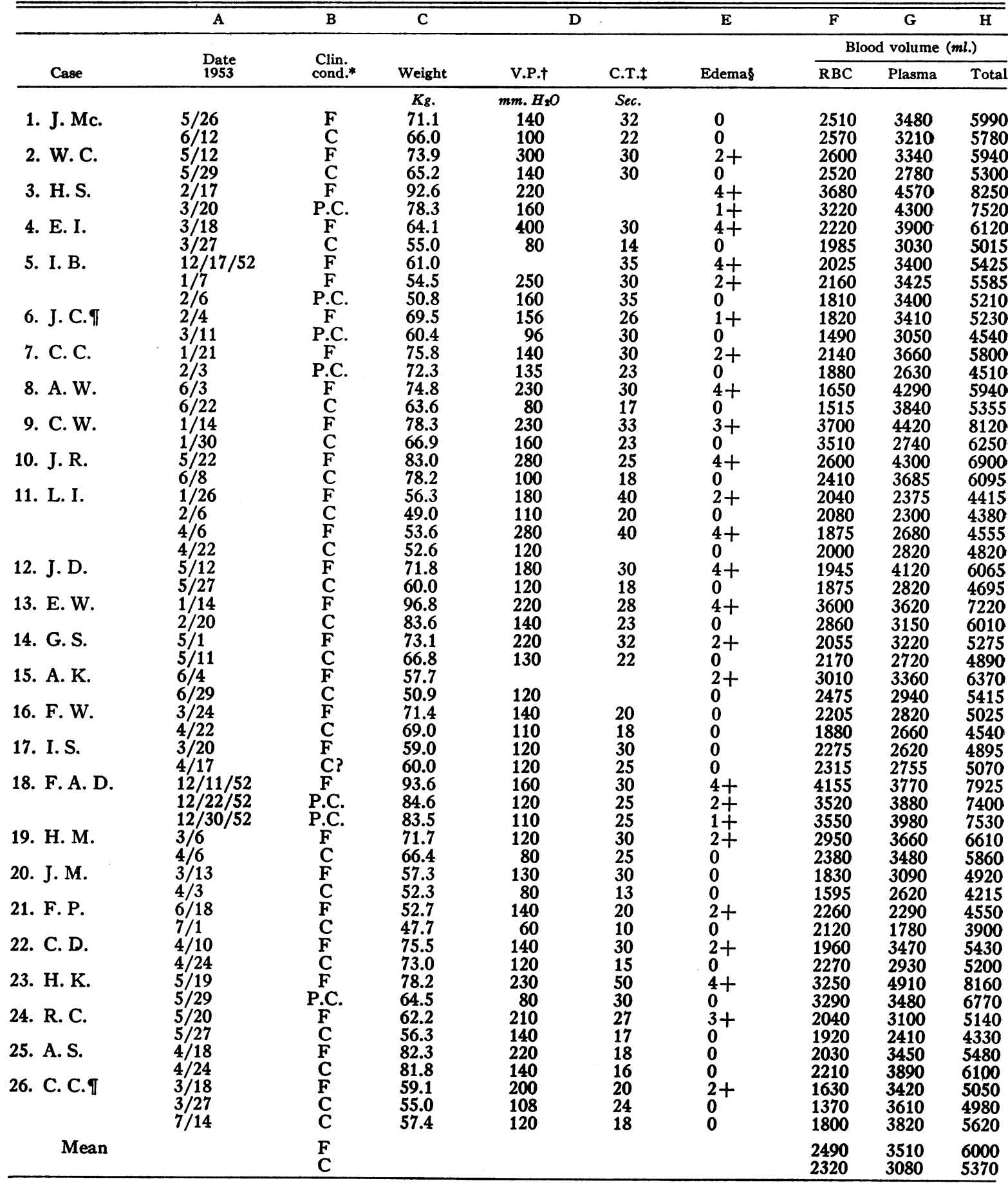

* C-Compensated.

† V.P.-Venous Pressure.

¥C.T.-Circulation time with Decholin@8.

P.C.-Fartially Compensated.

8 Grading of edema: $1+=$ mild ankle edema; $2+=$ ankle and pre-tibial edema, moderate; $3+=$ marked edema of the lower extremities; $4+=$ generalized anasarca (severe edema of lower extremities, sacrum, skin including abdominal wall, and ascites).

I Cases No. 6 (J. C.) and No. 26 (C. C.) have not been included in the mean values for RBC volume and total body relative cell volume/peripheral hematocrit value ratio $(\mathrm{L} / \mathrm{M})$, because of other factors tending to decrease erythrocyte
volume. For explanation see Text. 
TABLE I-Continued

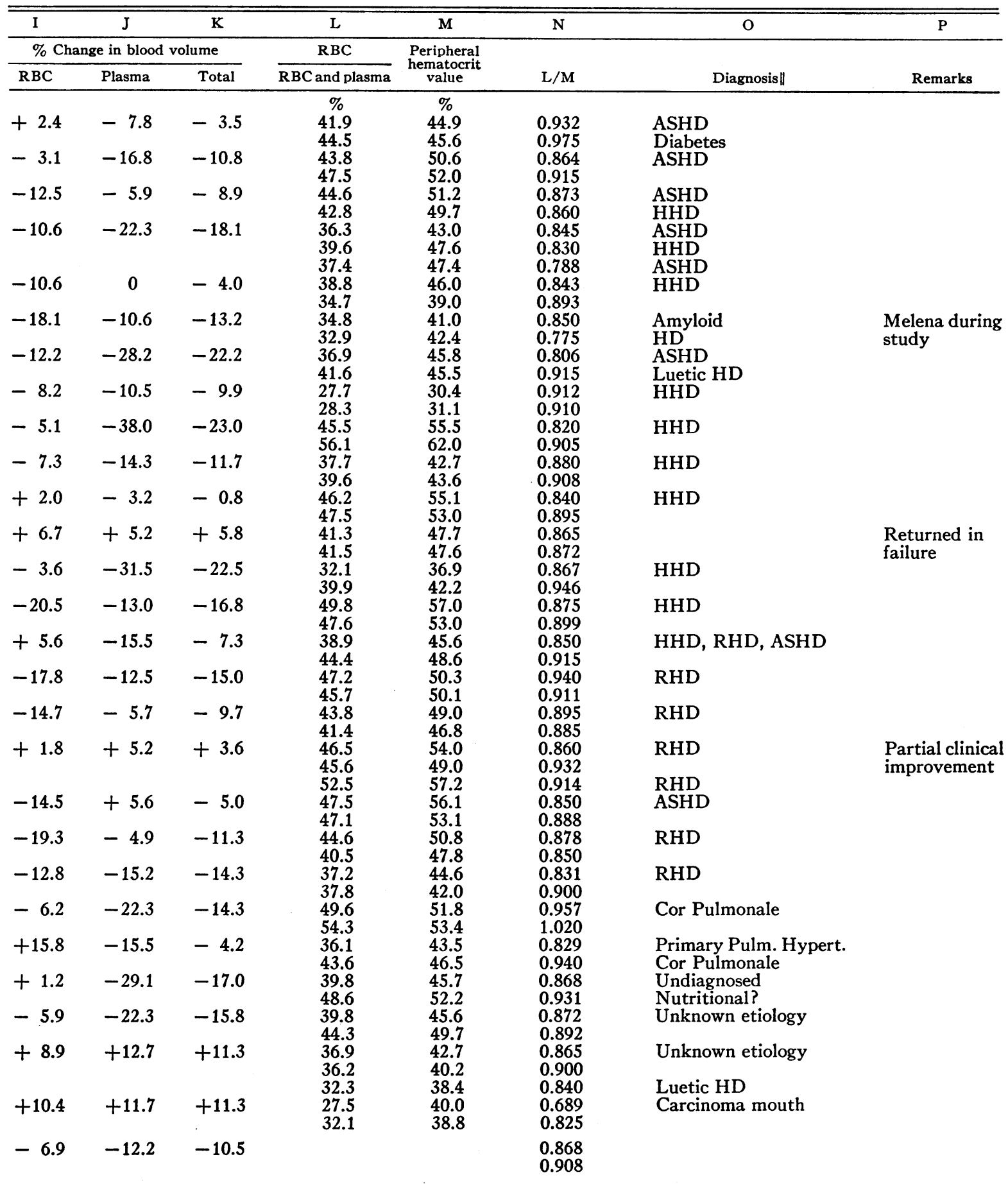

|| ASHD-Arteriosclerotic Heart Disease; HHD-Hypertensive Heart Disease; RHD-Rheumatic Heart Disease. 
Ratio of total body relative cell volume to venous hematocrit values

In the majority, compensation was associated with an increase in the ratio,

\section{total body relative cell volume venous hematocrit value}

(Table I, column N, Figure 2). In addition, in one instance, a decrease in this ratio was noted following relapse into congestive failure. Furthermore, the mean ratio in 24 patients in congestive heart failure $(0.868 \pm 0.008)$ was considerably lower than that of a control group of non-cardiac subjects $(0.937 \pm 0.009)$ and rose following compensation $(0.908 \pm 0.008)$. Two subjects are not included in these calculations because of the influence of other factors on red cell volume. In one (No. 6, J. C.) there was gastrointestinal bleeding during the study, and in the other (No. 26, C. C.)

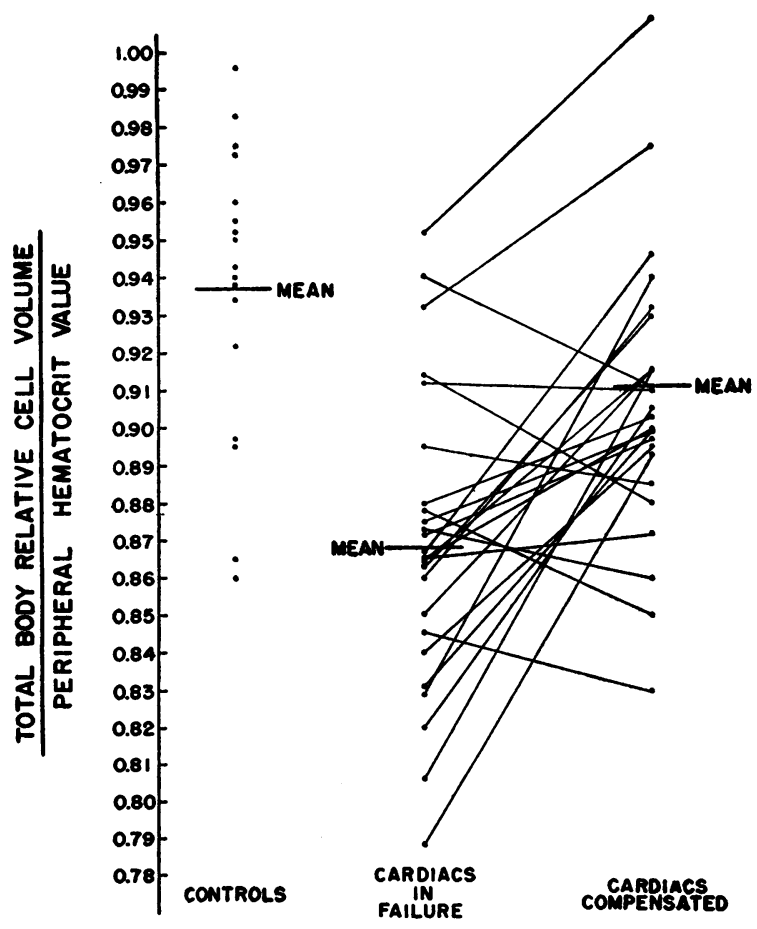

Fig. 2. Comparison of the Ratios,

Total Body Relative Cell Volume of Control Subjects with Those of Patients in Heart Failure and after Compensation

Cases No. 6 (J. C.) and No. 26 (C. C.) are not included. For explanation see Text. a changing blood picture accompanied roentgen therapy of a laryngeal carcinoma.

Our observations fail to show a correlation between the magnitude of the fall in venous pressure and that of the plasma volume.

\section{DISCUSSION}

The accurate measurement of plasma volume remains a matter of some dispute. Direct determinations with plasma soluble dyes $(9-14,22-24)$ or radioiodinated albumin (16) have in general shown values higher than those calculated from measured red cell volumes and the venous hematocrit values. This discrepancy has been interpreted by some $(9-14,16,22)$ as resulting from a true difference between the relative cell volume of the entire body and that of the large vessels. Others $(5,6,25)$ have concluded that the dye methods are in error and that total body relative cell volume does not differ significantly from the venous hematocrit value (5). Although there is no positive data to support the latter concept (5), several arguments derived from indirect evidence must be evaluated.

The origin of the dispute lies in the observation that the plasma soluble substances employed have a space of distribution greater than that of tagged erythrocytes. To conclude from this alone that the former must be distributed extravascularly is to imply that the relative cell volume is the same throughout the body. However, splenic blood, which is rapidly exchangeable with injected $\mathrm{Fe}$ tagged erythrocytes, has a much higher hematocrit value than blood in the large vessels (26). In subjects with markedly enlarged spleens, the ratio,

$$
\frac{\text { total body relative cell volume }}{\text { venous hematocrit value }}
$$

is frequently over 1.00 (27), a circumstance which is very rarely observed in other subjects. In the normal dog this ratio averages almost 1.00 as determined by Evans Blue and $\mathrm{P}^{32}$ tagged erythrocytes. Yet it cannot be concluded that in this species the relative cell volume is the same in all vessels, for the ratio decreases to 0.90 following splenectomy (28). Furthermore, there is direct evidence that the relative cell volume of minute vessels is lower than that of the large vessels. Krogh (29) noted that there is a marginal lining of plasma in small vessels through which there 
flows an axial stream of whole blood, and Fåhraeus (30) demonstrated a similar phenomenon in glass capillary tubes by observing that the relative amount of plasma increases as the diameter of the tube is reduced. Ebert and Stead (31) demonstrated a lower hematocrit value in blood obtained from the small vessels of the forearm than in the large vessels.

Other critics of the dye methods have pointed to an early rapid leak out of the vascular system, attributed to delayed binding by serum albumin (13), or to phagocytosis of a foreign substance (32). These objections cannot be applied to $\mathrm{I}^{131}$ labeled serum albumin. Schultz, Hammarsten, Heller, and Ebert (33) demonstrated that the amount of $\mathrm{I}^{131}$-labeled albumin appearing in thoracic duct lymph during the period of plasma volume determination does not significantly influence the measurement of plasma volume. In the dog, at least, intravenously administered tagged serum proteins equilibrate more rapidly with thoracic duct lymph than the lymph from the neck or limbs (34).

The arterial time concentration curves of $\mathrm{I}^{131}$ labeled albumin and $\mathrm{P}^{\mathbf{3 2}}$ tagged erythrocytes do not differ significantly between 1 or $1 \frac{1}{2}$ minutes and 15 minutes, and venous concentrations of $\mathrm{I}^{181}$ labeled albumin do not change significantly between 4 and 20 minutes after injection (16). Therefore, if the difference between the spaces of distribution of ${ }^{131}$-labeled albumin and tagged red cells is to be attributed to leakage from the blood stream, this leakage must be completed within a very few minutes. The liver has been suggested as the site of an early leak of T-1824 dye from the blood stream (25). The possibility of rapid $\mathrm{I}^{181}$ labeled albumin accumulation by the liver has previously been evaluated (35) by recording a continuous radioactive assay over the liver from the time of injection. After an initial rapid rise during the first minute, the level of radioactivity remained at a plateau without significant change for the next hour. This observation was confirmed in two cardiac patients of the present series. The possibility of leak into the liver during the first minute was investigated in the rabbit. Following simultaneous injection of $\mathrm{P}^{32}$-tagged rabbit erythrocytes and I ${ }^{131}$-labeled human serum albumin into the portal vein, the apparent volumes of distribution in the liver during the first circulation, as determined from hepatic vein samples, did not differ by more than 2 per cent.

The studies of other investigators (26) showed a higher $\mathrm{I}^{131}$-albumin/Fe-tagged erythrocyte ratio in most organs than in the large blood vessels. Thus, if an early rapid loss of $\mathrm{I}^{131}$-albumin from the blood stream is to explain these findings, this loss must occur throughout the body. It appears unlikely, that within the first few minutes, iodinated albumin exchanges with a diffusely distributed extravascular albumin pool, equivalent in magnitude to approximately 15 per cent of the total plasma albumin. Furthermore, the similar volumes of distribution of bovine serum proteins, T-1824 and pneumococcus polysaccharide S III (36) in animals and of $\mathrm{I}^{131}$-labeled serum albumin and gamma globulin in humans (37) indicate that any such diffusely distributed compartment which equilibrates so rapidly with plasma should be regarded as associated physiologically with plasma volume regardless of its anatomic boundaries.

It might be claimed on theoretical grounds that $I^{131}$ serum proteins or protein bound dyes do not measure exactly the plasma volume since there is a concentration of plasma proteins during filtration of fluid from the arterial ends of the capillaries. However, since the capillary bed comprises only about 5 per cent of the total blood volume (38) and the average hemoconcentration is not likely to exceed that in the glomerular capillaries (about 20 per cent), the error in the plasma volume determination due to non-uniform protein concentration is of the order of 1 per cent. In our opinion, therefore, until direct evidence to the contrary is presented, the determination of plasma volume with I ${ }^{131}$-labeled albumin must be considered to be on a more valid basis than estimates calculated from measured red cell volumes and peripheral vessel hematocrit values.

Recently, other investigators (5-7) concluded that there was no consistent expansion of blood volume in heart failure. In fact, following compensation, an increase in blood volume was not infrequently noted (6). However, these conclusions were derived from studies with tagged red cells and were based on the assumption that total body relative cell volume is identical with the peripheral vessel hematocrit value. In the present study there were a number of cases in which a decrease in plasma volume following compensation 
TABLE II

\begin{tabular}{|c|c|c|}
\hline Case & $\begin{array}{c}\text { Measured } \\
\text { change in } \\
\text { plasma } \\
\text { volume }\end{array}$ & $\begin{array}{l}\text { Calculated } \\
\text { change in } \\
\text { plasma } \\
\text { volume }\end{array}$ \\
\hline $\begin{array}{l}\text { 1. J. Mc. } \\
\text { 11. L. I. } \\
\text { 20. J. M. } \\
\text { 22. C. D. } \\
\text { 21. F. P. } \\
\text { 2. W. C. } \\
\text { 7. C. C. } \\
\text { 14. G. S. } \\
\text { 9. C. W. } \\
\text { 12. J. D. } \\
\text { 23. H. K. } \\
\text { 10. J. R. } \\
\text { 13. E. W. }\end{array}$ & $\begin{aligned} & m l . \\
&- 270 \\
&- 75 \\
&- 470 \\
&- 540 \\
&- 510 \\
&- 560 \\
&- 1030 \\
&- 500 \\
&- 1680 \\
&- 1300 \\
&-1430 \\
&= 615 \\
&- 470\end{aligned}$ & $\begin{array}{l}m l . \\
-\quad 10 \\
+180 \\
-65 \\
+120 \\
-250 \\
-200 \\
-280 \\
-155 \\
-790 \\
-760 \\
-750 \\
-380 \\
-160\end{array}$ \\
\hline $\begin{array}{l}\text { Mean of all cases } \\
\text { studied }\end{array}$ & -430 & -170 \\
\hline
\end{tabular}

would have remained undetected or would have been interpreted as an increase if calculations from erythrocyte volumes and hematocrit values alone were relied upon. In several other cases the magnitude of fall in plasma volume would have appeared much less striking (Table II). The mean fall in plasma volume for the entire group would have been calculated as 6 per cent compared to the measured decrease of 12.2 per cent. The results of the present investigation thus suggest why workers using tagged red cells alone failed to find much change in plasma volume following treatment of heart failure. However, regardless of the methods of calculation employed, the values for red cell and plasma volume in congestive heart failure, which have been obtained in the present study, indicate definite increases above normal.

The cause of the increased plasma volume in heart failure is not established. Starling (39) believed that a fall in cardiac output leads to reflex vasoconstriction, and that the consequent reduction in intracapillary pressure results in absorption of interstitial fluid into the circulation. Evidence in favor of this view has been reviewed elsewhere (40). Warren and Stead (41) have postulated that the increase in interstitial fluid tension produced by edema promotes an increase in plasma volume by upsetting the balance of factors regulating net transcapillary fluid exchange. Little support is offered to this concept by the results obtained in the present study, since plasma volumes frequently remained at higher than normal levels following cardiac compensation even in the absence of edema.

The mechanism of the observed decrease in circulating red blood cell volume with compensation is not clear. Waller, Blumgart, and Volk (42) found evidence of red cell destruction in heart failure. However, Watson (43) failed to observe any increase in fecal urobilinogen in cardiac decompensation. Mollison (44) has remarked on the absence of a normal hemolytic mechanism operating to rid the body of excess erythrocytes, and Fryers and Berlin (45) have demonstrated in rats that additional red cells formed in response to low barometric pressure have a normal life span after return to sea level environment. However, a decrease in red cell volume of as much as 25 per cent over a one month period can be accounted for by a cessation of blood formation, since the average normal red cell life span is about 120 days (44). Other investigators (46) have shown that in human subjects who move from high altitudes to sea level, the red cell iron turnover rate decreases to one-tenth of the initial value, approaching that seen in aplastic anemia. Therefore, the magnitude of the fall in erythrocyte volume observed in this series could be explained by reduced or arrested red cell formation without increased red cell destruction. Hyperplasia of the bone marrow in congestive heart failure with return to normal after compensation has been noted by Ott (47). Hypoxia of the marrow due to poor blood flow or low arterial $\mathrm{O}_{2}$ tension, secondary to heart failure, is the probable stimulus for the increased erythropoiesis.

\section{SUMMARY AND CONCLUSIONS}

1. Red cell and plasma volumes were determined independently in 26 subjects in heart failure and after compensation.

2. Mean values for red blood cell volumes and plasma volumes were elevated above those of control subjects and fell with compensation.

3. The ratio, $\frac{\text { total body relative cell volume, }}{\text { venous hematocrit value }}$ was observed to be decreased in failure and to rise with compensation in the majority of cases.

4. When plasma volumes are indirectly calculated from measured red cell volumes and hemato- 
crit readings, significant changes may remain undetected.

\section{ACKNOWLEDGMENTS}

Acknowledgment with thanks for aid received during this study is made to the following: Dr. Bernard Straus, Chief of the Medical Service and Dr. Louis Kapp, Chief of the Cardiac Section for their cooperation and interest in this work; Mr. Paul Newman of the Medical Illustration Department for the charts; Mrs. Florence Cavanagh, Mrs. Frieda Steiner, and Miss Eve Spelke for secretarial assistance.

\section{REFERENCES}

1. Gibson, J. G., 2nd, and Evans, W. A., Jr., Clinical studies of the blood volume. III. Changes in blood volume, venous pressure and blood velocity rate in chronic congestive heart failure. J. Clin. Invest., 1937, 16, 851.

2. Harris, A. W., and Gibson, J. G., 2nd, Clinical studies of the blood volume. VII. Changes in blood volume in Bright's disease with or without edema, renal insufficiency, or congestive heart failure, and in hypertension. J. Clin. Invest., 1939, 18, 527.

3. Seymour, W. B., Pritchard, W. H., Longley, L. P., and Hayman, J. M., Jr., Cardiac output, blood and interstitial fluid volumes, total circulating serum protein, and kidney function during cardiac failure and after improvement. J. Clin. Invest., 1942, 21, 229.

4. Meneely, G. R., and Kaltreider, N. L., A study of the volume of the blood in congestive heart failure. Relation to other measurements in fifteen patients. J. Clin. Invest., 1943, 22, 521.

5. Ross, J. F., Chodos, R. B., Baker, W. H., and Freis, E. D., The blood volume in congestive heart failure. Tr. A. Am. Physicians, 1952, 65, 75.

6. Prentice, T. C., Berlin, N. I., Hyde, G. M., Parsons, R. J., Lawrence, J. H., and Port, S., Total red cell volume, plasma volume, and sodium space in congestive heart failure. J. Clin. Invest., 1951, 30, 1471.

7. Eisenberg, S., The effect of congestive heart failure on the blood volume as determined by radioactive chromium-tagged red cells. Clinical Research Proceedings, 1953, 1, 77.

8. Reeve, E. B., Use of radioactive phosphorus for the measurement of red-cell and blood volume. Brit. M. Bull., 1952, 8, 181.

9. Barnes, D. W. H., Loutit, J. F., and Reeve, E. B., A comparison of estimates of circulating red blood cell volume given by the Ashby marked red cell method and the T-1824-haematocrit method in man. Clin. Sc., 1948, 7, 135.

10. Gibson, J. G., 2nd, Peacock, W. C., Seligman, A. M., and Sack, T., Circulating red cell volume measured simultaneously by the radioactive iron and dye methods. J. Clin. Invest., 1946, 25, 838.
11. Hahn, P. F., Ross, J. F., Bale, W. F., Balfour, W. M., and Whipple, G. H., Red cell and plasma volumes (circulating and total) as determined by radio iron and by dye. J. Exper. Med., 1942, 75, 221.

12. Hevesy, G., Köster, K. H. Sørensen, G., Warburg, E., and Zerahn, K., The red corpuscle content of the circulating blood determined by labelling the erythrocytes with radio-phosphorus. Acta med. Scandinav., 1944, 116, 561.

13. Meneely, G. R., Wells, E. B., and Hahn, P. F., Application of the radioactive red cell method for determination of blood volume in humans. Am. J. Physiol., 1947, 148, 531.

14. Nachman, H. M., James, G. W., III, Moore, J. W., and Evans, E. I., A comparative study of red cell volumes in human subjects with radioactive phosphorous tagged red cells and T-1824 dye. J. Clin. Invest., 1950, 29, 258.

15. Stead, E. A., Jr., and Ebert, R. V., Relationship of the plasma volume and the cell plasma ratio to the total red cell volume. Am. J. Physiol., 1941, 132, 411.

16. Berson, S. A., and Yalow, R. S., The use of $K^{*}$ or $P^{* 2}$ labeled erythrocytes and $I^{\text {sit }}$ tagged human serum albumin in simultaneous blood volume determinations. J. Clin. Invest., 1952, 31, 572.

17. Berson, S. A., Yalow, R. S., Azulay, A., Schreiber, S., and Roswit, B., The biological decay curve of $P^{23}$ tagged erythrocytes. Application to the study of acute changes in blood volume. J. Clin. Invest., 1952, 31, 581.

18. Vazquez, O. N., Newerly, K., Yalow, R. S., and Berson, S. A., Determination of trapped plasma in the centrifuged erythrocyte volume of normal human blood with radioiodinated ( $\left.\mathrm{I}^{131}\right)$ human serum albumin and radiosodium $\left(\mathrm{Na}^{24}\right)$. J. Lab. \& Clin. Med., 1952, 39, 595.

19. Gibson, J. G., 2nd, and Evans, W. A., Jr., Clinical studies of the blood volume. I. Clinical application of a method employing the Azo dye "Evans Blue" and the spectrophotometer. J. Clin. Invest., 1937, 16, 301.

20. Perera, G. A., The effect of significant weight change on the predicted plasma volume. J. Clin. Invest., 1946, 25, 401.

21. Henschel, A., Mickelson, O., Taylor, H. L., and Keys, A., Plasma volume and thiocyanate space in famine edema and recovery. Am. J. Physiol., 1947, 150, 170.

22. Smith, H. P., Arnold, H. R., and Whipple, G. H., Blood volume studies. VII. Comparative values of Welcker, carbon monoxide and dye methods for blood volume determinations. Accurate estimation of absolute blood volume. Am. J. Physiol., 1921, 56, 336.

23. Wasserman, L. R., Yoh, T., and Rashkoff, I. A., Blood volume determination: comparison of T-1824 and $\mathrm{P}^{32}$ labeled red cell methods. J. Lab. \& Clin. Med., 1951, 37, 342. 
24. Scott, H. W., Jr., Elliott, S. R., II, and Clay, R. C., Blood volume in congenital heart disease: simultaneous measurements with Evans Blue and radioactive phosphorus. Bull. Johns Hopkins Hosp., 1951, 89, 121.

25. Peters, J. P., The role of sodium in the production of edema. New England J. Med., 1948, 239, 353.

26. Gibson, J. G., 2nd, Seligman, A. M., Peacock, W. C., Aub, J. C., Fine, J., and Evans, R. D., The distribution of red cells and plasma in large and minute vessels of the normal dog, determined by radioactive isotopes of iron and iodine. J. Clin. Invest., 1946, 25, 848.

27. Rothschild, M. A., and Bauman, A., The effect of marked enlargement of the spleen on the ratio between total body average relative cell volume and peripheral hematocrit value. To be published.

28. Reeve, E. B., Gregersen, M. I., Allen, T. H., and Sear, $H$., Distribution of cells and plasma in the normal and splenectomized dog and its influence on blood volume estimates with $\mathrm{P}^{32}$ and $\mathrm{T}-1824$. Am. J. Physiol., 1953, 175, 195.

29. Krogh, A., The Anatomy and Physiology of Capillaries. New Haven, Yale University Press, ed. 2, 1929.

30. Fåhraeus, R., The suspension stability of the blood. Physiol. Rev., 1929, 9, 241.

31. Ebert, R. V., and Stead, E. A., Jr., Demonstration that the cell plasma ratio of blood contained in minute vessels is lower than that of venous blood. J. Clin. Invest., 1941, 20, 317.

32. Cruickshank, E. W. H., and Whitfield, I. C., The behaviour of T-1824 (Evan's Blue) in circulating blood and a modified method for the estimation of plasma volume. J. Physiol., 1945, 104, 52.

33. Schultz, A. L., Hammarsten, J. F., Heller, B. I., and Ebert, R. V., A critical comparison of the T-1824 dye and iodinated albumin methods for plasma volume measurement. J. Clin. Invest., 1953, 32, 107.

34. Cope, O., and Moore, F. D., A study of capillary permeability in experimental burns and burn shock using radioactive dyes in blood and lymph. J. Clin. Invest., 1944, 23, 241.

35. Berson, S. A., Yalow, R. S., Post, J., Wisham, L. H., Newerly, K. N., Villazon, M. J., and Vazquez, O. N., Distribution and fate of intravenously administered modified human globin and its effect on blood volume. Studies utilizing $I^{2 n}$ tagged globin. J. Clin. Invest., 1953, 32, 22.

36. Gregersen, M. I., Boyden, A. A., and Allison, J. B., Direct comparison in dogs of plasma volume measured with T-1824 and with antigens. Am. J. Physiol., 1950, 163, 517.

37. Schreiber, S. S., Yalow, R. S., and Berson, S. A., Unpublished data.

38. Green, H. D., Circulatory System : Physical Principles, in Medical Physics, Vol. II, Glasser, O., ed., Chicago, The Year Book Publishers, 1950, p. 228.

39. Starling, E., The Herter Lectures (New York, 1908) on the fluids of the body. Chicago, W. T. Keener and Co., 1909, p. 186.

40. Berson, S. A., Blood volume in health and disease. Presented at the 26th Graduate Fortnight at the New York Academy of Medicine, October 30, 1953. To be published.

41. Warren, J. V., and Stead, E. A., Jr., Fluid dynamics in chronic congestive heart failure. An interpretation of the mechanisms producing the edema, increased plasma volume and elevated venous pressure in certain patients with prolonged congestive failure. Arch. Int. Med., 1944, 73, 138.

42. Waller, J. V., Blumgart, H. L., and Volk, M. C., Studies of the blood in congestive heart failure with particular reference to reticulocytosis, erythrocyte fragility, bilirubinemia, urobilinogen excretion and changes in blood volume. Arch. Int. Med., 1940, 66, 1230.

43. Watson, C. J., Studies of urobilinogen. III. The per diem excretion of urobilinogen in the common forms of jaundice and disease of the liver. Arch. Int. Med., 1937, 59, 206.

44. Mollison, P. L., Blood Transfusion in Clinical Medicine. Springfield, Ill., Charles C Thomas, 1951, p. 456.

45. Fryers, G. R., and Berlin, N. I., Mean red cell life of rats exposed to reduced barometric pressure. Am. J. Physiol., 1952, 171, 465.

46. Lawrence, J. H., Huff, R. L., Siri, W., Wasserman, L. R., and Hennessey, T. G., A physiological study in the Peruvian Andes. Acta med. Scandinav., 1952, $142,117$.

47. Ott, A., Uber Blutmenge und Knochenmarkschefund bei Herzinsuffizienz. Deutsches Arch f. Klin. Med., 1939-40, 185, 176. 